\title{
Congenital Epulis of the Newborn: A Case Report and Literature Review
}

\author{
Eldho Babu ${ }^{1}$, Gayathri Kamalasanan ${ }^{2}$, Prathima $\mathrm{GS}^{3}$, Muthukrishnan Kavitha ${ }^{4}$
}

\begin{abstract}
Congenital epulis is a rare benign lesion of new-born and occurs mostly as a single tumor. A new-born infant with congenital epulis is a striking sight for both parents and health care professionals involved in neonatal care. The tumor has a female predilection with the female to male ratio being 10:1. These tumors in the infant's mouth are remarkably large, occupying much of the oral cavity and posing a risk of airway obstruction and it can interfere with the feeding. Although the clinical presentation of the congenital tumor is rather distressing, owing to its size and aggressive appearance, it is very much necessary that the attending pediatricians, pediatric surgeon be cognizant of the nature of this rare yet benign congenital tumor. The purpose of this article is to present a case report documenting the clinical presentation and management of Congenital Epulis on the anterior maxillary alveolus in a three-day old female patient.

Keywords: Congenital epulis, Neonatal epulis, Surgical excision.

International Journal of Clinical Pediatric Dentistry (2021): 10.5005/jp-journals-10005-2078
\end{abstract}

\section{INTRODUCTION}

Congenital epulis, also known as Neumann's' Tumor, is a sporadic benign soft tissue lesion of obscure etiology. The lesion was first described in 1871 by Neumann and hence named Newmann's Tumor. ${ }^{1,2}$ Congenital Epulis is also acknowledged as congenital granular cell lesion, gingival granular cell tumor of the newborn, congenital epulis of the newborn, congenital granular cell myoblastoma, and granular cell fibroblastoma. ${ }^{3}$ It has a close resemblance with granular cell myloblastoma.

The term epulis derives from the Greek word meaning "on the gum" or "gum boil" and has been unfortunately used for a variety of benign tumors and tumor-like conditions having dissimilar structures and histogenesis. ${ }^{4,5}$ Congenital epulis is usually presents at birth as a prominent palpable mass arising from the gingival mucosa of the maxilla or mandible. ${ }^{2}$ There is a marked female predominance of 10:1. ${ }^{4}$ The incidence rates are found to be $0.0006 \%$ at a center in wales and epulis accounted for $10.8 \%$ of all the oral lesions in a center in India. ${ }^{5}$

The lesions occur sporadically, and no familial predispositions are noted. Usually, congenital epulis unveil as a solitary lesion. Although, multiple lesions were noted in $10 \%$ of the cases. ${ }^{4}$ The lesion clinically is presented in the form of pedunculated, nonulcerated pink mass of various sizes from few $\mathrm{mm}$ to $9 \mathrm{~cm}$ in diameter. $^{1-6}$

Diagnosis is generally based on clinical grounds alone. ${ }^{7}$ Few cases of spontaneous regression have also been reported. ${ }^{8}$ Congenital Epulis can impede feeding and respiration and hence, the recommended treatment is surgical excision under local or general anesthesia. To reduce the risk of damage to the underlying alveolar bone and developing tooth buds minimally invasive surgery should be done. ${ }^{9}$

The exact etiology of Congenital epulis is not known, but numerous theories have been postulated. This case report documents the presentation and surgical management of 3 year old female baby with congenital epulis of the right maxillary alveolar ridge (Fig 1).
'Department of Pediatric and Preventive Dentistry, St. Gregorios Dental College, Kothamangalam, Kerala, India

${ }^{2}$ Department of Pediatric and Preventive Dentistry, Indira Gandhi Institute of Dental Sciences, Kollam, Kerala, India

${ }^{3}$ Department of Pedodontics and Preventive Dentistry, Indira Gandhi Institute of Dental Sciences, Puducherry, India

${ }^{4}$ Indira Gandhi Institute of Dental Sciences, Puducherry, India

Corresponding Author: Eldho Babu, Pediatric and Preventive Dentistry, St. Gregorios Dental College, Kothamangalam, Kerala, India, Phone: +91 9496566246, e-mail: eldhobabu@yahoo.com

How to cite this article: Babu E, Kamalasanan G, Prathima GS, et al. Congenital Epulis of the Newborn A Case Report and Literature Review. Int J Clin Pediatr Dent 2021;14(6):833-837.

Source of support: Nil

Conflict of interest: None

\section{Case Description}

A three-day old female child with a lobulated swelling in the upper jaw was referred from the Department of Paediatrics to the Department of Pediatric and Preventive Dentistry. Even though respiratory distress was not evident in the child, the mother informed about the difficulty while breastfeeding the baby. Delivery was cesarean at full term and both maternal and paternal history was noncontributory. Medical history was also not relevant.

On clinical examination, a pink, lobulated, pedunculated, nontender, smooth surfaced mass measuring $2 \times 2 \times 1 \mathrm{~mm}$ was noticed on the maxillary alveolar ridge. It was firm in consistency. Adjacent tissue appeared normal on examination. The patient underwent surgical excision, and the tissue was sent to Department of Oral Pathology for Histopathological examination (Figs 2 and 3 ).

Postoperative course was normal. Feeding started 5 hours after surgery and, the patient was discharged 2 days after the intervention. Patient was recalled after every 2 weeks and no recurrence was found. Based on the clinical and histopathological 


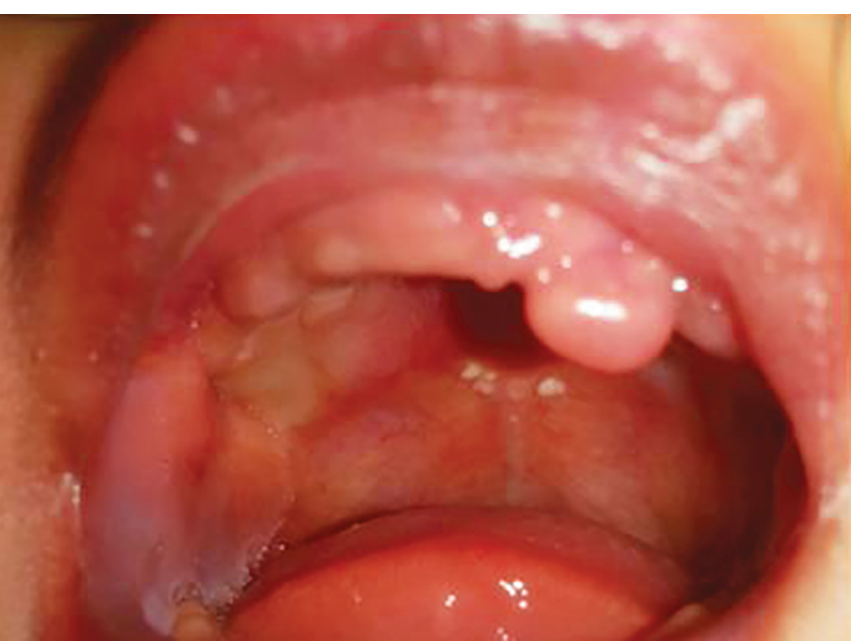

Fig. 1: Appearance of an intra oral mass arising from gingiva of the anterior maxilla

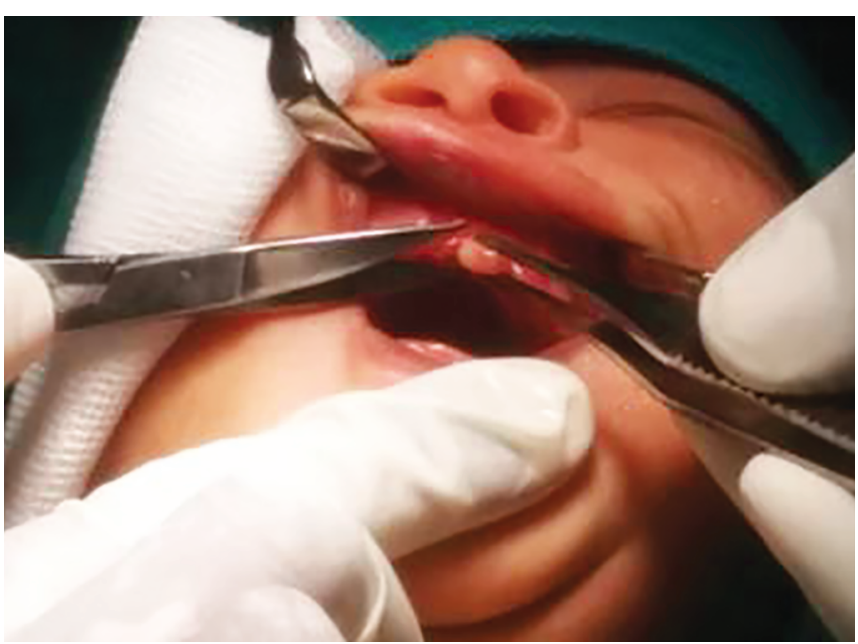

Fig. 2: Surgical excision of the lesion

findings, the lesion was suggestive of Congenital epulis (Fig. 4, Table 1).

\section{Histopathological Feature}

Histopathological report of the $\mathrm{H}$ and E-stained section revealed lesional tissue in the connective tissue area, where plenty of polygonal shaped to round shaped cells with granular cytoplasm and round centrically placed nucleus are noted. Associated with this, plenty of capillaries and blood vessels are noticed. The deeper areas show spindle shaped cells. The overlying epithelium is stratified squamous parakeratinised and is atrophic in nature. Which is suggestive of congenital epulis Figures $5 \mathrm{~A}$ to $\mathrm{C}$.

\section{Discussion}

Congenital epulis is commonly found in neonates as a mass derived from gingiva. ${ }^{1}$ The clinical presentation of which shows a lobular or ovoid, sessile or pedunculated swelling enveloped by a smooth mucosal surface. ${ }^{1,10,11}$ The most affected site is maxilla, which is 3 times more frequently than the mandible., ${ }^{6,12,13-18}$ The lesion has a site predilection for the maxillary alveolar process, lateral to the midline in the region of the primary canine and lateral

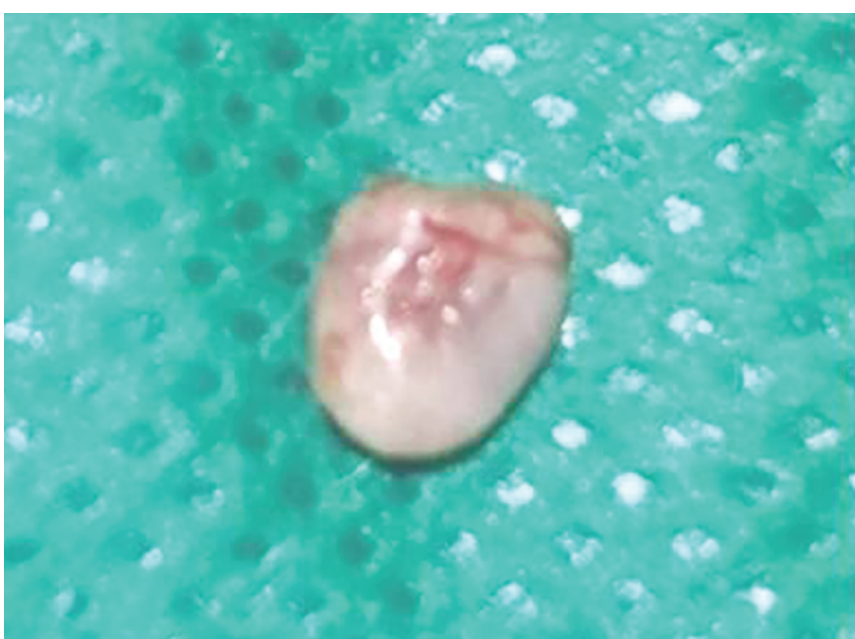

Fig. 3: Excised specimen

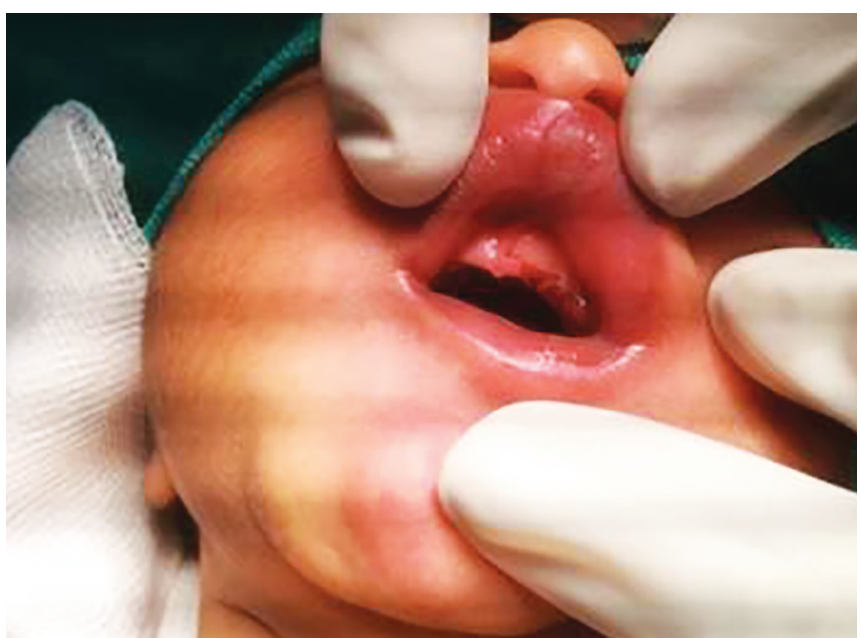

Fig. 4: Appearance of the alveolar ridge after the excision of the pedunculated lesion

incisor, and is seen rarely in tongue. ${ }^{4}$ There are many distinguishing features, such as occurrence exclusively in the neonate, typical site, plexiform arrangement of capillaries, and lack of pseudo epitheliomatous hyperplasia. ${ }^{4}$

The frequency of occurrence in the canine and incisor region can be attributed to the fact that the maxillary anterior region is a common site for supernumerary teeth. An endogenous hormonal influence has been proposed to explain the female prevalence and the intrauterine growth, but this theory is not proved since detectable oestrogen and progesterone receptors within the lesions are absent. ${ }^{5}$ Histologically, presence of odontogenic islands is suggestive of odontogenic anomalous origin or hamartomas derived from odontogenic epithelial rests. ${ }^{1}$

The precise origin of Congenital Epulis still remains unclear. CGTs are considered to arise from Schwann Cells, and hence show strong reactivity to S-100 protein. Various theories of the origin of Congenital Epulis includes myoblastic, neurogenic, odontogenic, fibroblastic, and histocytic origin. Lack et al. believe it to be basically reactive in origin. It has been suggested that the occurrence of Congenital Epulis solely in female neonates indicates a hormonal mechanism of development. ${ }^{8}$ 
Table 1: Reported cases of congenital Epulis

\begin{tabular}{|c|c|c|c|c|c|c|c|}
\hline S.No & Year & Author & Age & Sex & Location & Size & Treatment \\
\hline 1 & 1995 & Sarihan $\mathrm{H}$ & 2 days & Male & $\begin{array}{l}\text { Anterior ridge of the } \\
\text { maxilla }\end{array}$ & $3 \times 2.5 \times 2 \mathrm{~cm}$ & $\begin{array}{l}\text { Excision under local } \\
\text { anesthesia }\end{array}$ \\
\hline 2 & 2001 & Lapid O & 1 day & Female & $\begin{array}{l}\text { Anterior part of the } \\
\text { maxillary alveolar } \\
\text { ridge }\end{array}$ & $2 \times 1 \mathrm{~cm}$ & Surgical resection \\
\hline 3 & 2002 & Marakoglu & 1 day & Female & $\begin{array}{l}\text { Anterior mandibular } \\
\text { ridge }\end{array}$ & $8 \times 4 \times 4 \mathrm{~mm}$ & $\begin{array}{l}\text { Nonsurgical manage- } \\
\text { ment }\end{array}$ \\
\hline 4 & 2003 & S. J Merrett & 1 day & & $\begin{array}{l}\text { Maxillary alveolus to } \\
\text { the left of the midline }\end{array}$ & - & Surgical excision \\
\hline 5 & 2005 & Parikh SJ & $\begin{array}{l}2 \text { yrs } 6 \\
\text { months }\end{array}$ & Female & $\begin{array}{l}\text { Right maxillary alveo- } \\
\text { lar ridge }\end{array}$ & $1.5 \times 0.5 \mathrm{~cm}$ & Surgical excision \\
\hline 6 & 2005 & Parikh SJ & 9 months & Male & $\begin{array}{l}\text { Left mandibular } \\
\text { alveolar ridge }\end{array}$ & $2 \mathrm{~cm}$ & Surgical excision \\
\hline 7 & 2006 & Sk Kannan & 2 day & $\begin{array}{l}\text { Female } \\
\text { child }\end{array}$ & $\begin{array}{l}\text { Maxillary alveolar } \\
\text { ridge }\end{array}$ & $1 \mathrm{~cm}$ & Surgical excision \\
\hline 8 & 2007 & Sakai VT & 8 months & Female & $\begin{array}{l}\text { Right maxillary alveo- } \\
\text { lar process }\end{array}$ & $1.4 \times 1.2 \times 1.2 \mathrm{~cm}$ & $\begin{array}{l}\text { Nonsurgical manage- } \\
\text { ment }\end{array}$ \\
\hline 9 & 2008 & $\begin{array}{l}\text { Mzubanzi ma- } \\
\text { bongo }\end{array}$ & $\begin{array}{l}4 \text { days } \\
\text { old }\end{array}$ & Female & $\begin{array}{l}\text { Masticator mucosa of } \\
\text { anterior mandibular } \\
\text { ridge }\end{array}$ & - & $\begin{array}{l}\text { Surgical excision under } \\
\text { general anesthesia }\end{array}$ \\
\hline 10 & 2009 & Bosanquet D & 1 day & Female & $\begin{array}{l}\text { Upper and lower } \\
\text { alveolar ridges }\end{array}$ & $4 \times 3 \times 3 \mathrm{~cm}$ & Surgical excision \\
\hline 11 & 2009 & Ritwik & 3 weeks & Female & $\begin{array}{l}\text { Right maxillary alveo- } \\
\text { lar process }\end{array}$ & $1.5 \mathrm{~cm}$ & $\begin{array}{l}\text { Nonsurgical manage- } \\
\text { ment }\end{array}$ \\
\hline 12 & 2011 & Kayiran SM & 1 day & Female & $\begin{array}{l}\text { Anterior ventral sur- } \\
\text { face of the tongue }\end{array}$ & $2 \times 1 \times 0.6 \mathrm{~cm}$ & $\begin{array}{l}\text { Surgical excision } \\
\text { under general anesthesia }\end{array}$ \\
\hline 13 & 2013 & Nagpal R & 2 days & Female & $\begin{array}{l}\text { Maxillary ridge with- } \\
\text { out extension into } \\
\text { the nasal airway, soft } \\
\text { palate, floor of the } \\
\text { mouth, mouth, nose } \\
\text { or cranium [ }\end{array}$ & $4.0 \times 2.0 \times 4.0 \mathrm{~cm}$ & $\begin{array}{l}\text { Surgical excision under } \\
\text { general anesthesia }\end{array}$ \\
\hline 14 & 2015 & Kumar RM & 3days & Female & $\begin{array}{l}\text { Right side of the max- } \\
\text { illary alveolar ridge }\end{array}$ & $4.3 \mathrm{~cm} \times 3.2 \mathrm{~cm}$ & $\begin{array}{l}\text { Surgical excision under } \\
\text { general anesthesia }\end{array}$ \\
\hline 15 & 2016 & Wagdargi S & 1 day & Female & $\begin{array}{l}\text { Well-defined, pe- } \\
\text { dunculated, midline } \\
\text { round tumor mass in } \\
\text { oral cavity measuring }\end{array}$ & $3 \mathrm{~cm} \times 2 \mathrm{~cm}$ & $\begin{array}{l}\text { Surgical excision under } \\
\text { general anesthesia }\end{array}$ \\
\hline 16 & 2016 & Omisakin 0.0 & 1 month & Female & $\begin{array}{l}\text { Anterior alveolar ridge } \\
\text { of the mandible on } \\
\text { the left side }\end{array}$ & $3 \mathrm{~cm} \times 4 \mathrm{~cm} \times 5 \mathrm{~cm}$ & $\begin{array}{l}\text { Surgical excision under } \\
\text { general anesthesia }\end{array}$ \\
\hline 17 & 2018 & Kokobun K & 1 day & Female & $\begin{array}{l}\text { Elastic, pedunculated } \\
\text { smooth surface mass }\end{array}$ & $20 \times 10 \mathrm{~mm}$ & $\begin{array}{l}\text { Surgical Excision under } \\
\text { general anesthesia }\end{array}$ \\
\hline 18 & 2018 & Sarangal H & 3 days & Male & $\begin{array}{l}\text { Anterior maxillary } \\
\text { alveolus }\end{array}$ & $10 \times 12 \times 10 \mathrm{~mm}$ & $\begin{array}{l}\text { Excision done under } \\
\text { modified electrocautery } \\
\text { needle }\end{array}$ \\
\hline
\end{tabular}

The traditional management of the lesion has been complete surgical excision under either general anesthesia or local anesthesia within hours to days after birth. A case report of excision of Congenital Epulis using carbon dioxide laser under general anesthesia was reported in a two-day-old infant. In another case report, erbium, chromium: yttrium-scandiumgallium garnet ( $\mathrm{Er}, \mathrm{Cr}$ : YSGG) laser were used to remove a Congenital Epulis lesion. It has also been found that incomplete removal of Congenital Epulis will not cause the recurrence of the lesion. ${ }^{8}$ In another case report, the management of congenital epulis was done by excising it under Modified Electrocautery
Needle. ${ }^{9}$ Of the more than 200 cases of Congenital Epulis of the new born reported in the English literature, there have been eight case reports that have documented spontaneous regression. ${ }^{8}$ There have been recommendations in the literature to undertake an expectant, nonsurgical approach in cases of Congenital Epulis where there is no interference with feeding or respiration.

In such cases, regular monitoring of the lesion for regression has been advocated as an acceptable clinical approach. The reasoning is that the Congenital Epulis has an inherent tendency to involute without exhibiting postnatal growth. ${ }^{8}$ 


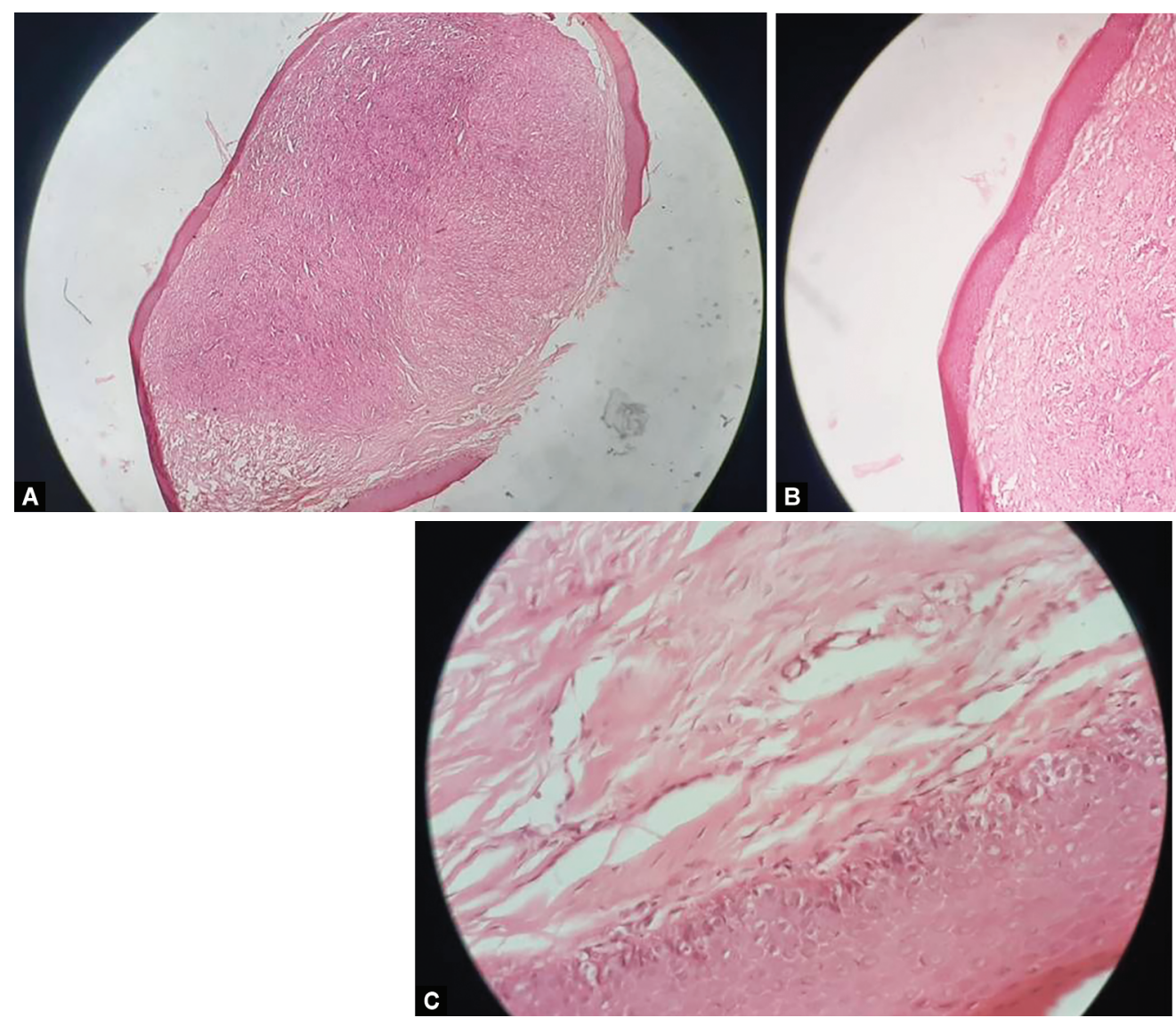

Figs 5A to C: Histological features: (A) H\&E, 4X; (B) H\&E, 10X; (C) H\&E, 40X

\section{Differential Diagnosis}

Differential diagnosis of Congenital epulis is done with the other neuroectodermic lesions of the oral cavity in the new-born like teratoma, leiomyoma, congenital dermoid cyst, congenital cystic choristoma, congenital fibrosarcoma, congenital lipoma, hemangioma, and granuloma. ${ }^{19}$

Despite the clinical and diagnostic knowledge of Congential epulis, precise prenatal diagnosis is difficult to achieve. A defined prenatal image of Congential epulis is possible only by means of accurate high-resolution ultrasonography at around the 31st gestational week, although this is not always possible. ${ }^{19,20}$

\section{References}

1. Wagdargi S, Patil RS, Arakeri G, et al. Congenital epulis in the newborn, review of the literature and report of a case. J Int Oral Health 2016;8(5):629-631.DOI: 10.1097/MPH.0b013e3 1818ab2f7

2. Nagpal R, Suryawanshi P, Malshe N, et al. Congenital epulis: case report and literature review. Indian J Neontal Med Res 2013;1(1):18-20. DOI: IJNMR/2013/5856.1975

3. Bosanquet D, Roblin G. Congenital epulis: a case report and estimation of incidence. Int J Otolaryngol 2009:508780. DOI: $10.1155 / 2009 / 508780$

4. Kayıran SM, Buyukunal C, Ince U, et al. Congenital epulis of the tongue: a case report and review of the literature. JRSM Short Rep 2011;2(7):62. DOI: 10.1258/shorts.2011.011048
5. Kumar RM, Bavle RM, Umashankar DN, et al. Congenital epulis of the newborn. J Oral Maxillofac Pathol 2015;19:407. DOI: 10.4103/0973-029X.174642

6. Marakoglu I, Gursoy UK, Marakoglu K. Congenital epulis: report of a case. ASDC J Dent Child 2002;69(2):191-125.

7. Jenkins HR, Hill CM: Spontaneous regression of congenital epulis of the newborn. Arch Dis Child 1989; 64: 145-147 DOI: 10.1136/ adc.64.1.145

8. Ritwik P, Brannon RB, Musselman RJ. Spontaneous regression of congenital epulis: a case report and review of the literature. J Med Case Rep 2010, 4:331. DOI: 10.1186/1752-1947-4-331

9. Sarangal $H, N a m d e v ~ R$ et al. Management of congenital epulis: a case report with review of literature. J South Asian Assoc Pediatr Dent 2018;1(2):58-60. DOI: 10.5005/jp-journals-10077-3014

10. Sarihan H, Gedík Y, Mocan H, et al. Congenital epulis. Case report Scand J Plast Reconstr Surg Hand Surg 1995;29(1):77-79. DOI: 10.3109/02844319509048429

11. Kokubun K, Matsuzaka K, Akashi Y, et al. Congenital epulis: a case and review of the literature. Bull Tokyo Dent Coll 2018;59(2):127-132 DOI: 10.2209/tdcpublication.2017-0028

12. Omisakin OO, Kache SA, Ajike SO. Congenital epulis: a report of two cases and review of the literature. Int J Med Biomed Res 2016;5(3):130134. DOI: 10.14194/ijmbr.5.3.4

13. Parikh SJ, Jain M. Congenital epulis : report of two cases. J Indian Acad Oral Med Radiol 2005;17:28-31

14. Lapid O, Shaco-Levy R, Krieger Y, et al. Congenital epulis. Pediatrics 2001;107(2):22-24. DOI: 10.1542/peds.107.2.e22

15. Kannan SK, Rajesh R. Congenital epulis - congenital granular cell lesion: a case report. J Indian Soc Pedod Prev Dent 2006;24(2):104-106. DOI: $10.4103 / 0970-4388.26026$ 
16. Sakai VT, Oliveira TM, Silva TC, et al. Complete spontaneous regression of congenital epulis in a baby by 8 months of age. Int J Paediatr Dent 2007;17(4):309-312. DOI: 10.1111/j.1365-263X.2006.00795.x

17. Merrett SJ, Crawford PJ. Congenital epulis of the newborn: a case report. Int J Paediatr Dent 2003;13(2):127-129. DOI: 10.1046/j.1365263x.2003.00435.x

18. Mabongo M, Wood NH, Lemmer J, et al. Congenital epulis. A case report. SADJ 2008;63(6):350-351. DOI: 10.3109/ 02844319509048429
19. Messina M, Severi FM, Buonocore G et al. Prenatal diagnosis and multidisciplinary approach to the congenital gingival granular cell tumor. J Pediatr Surg 2006; 41: 35-38. DOI: 10.1016/j. jpedsurg.2006.07.003

20. Kusukawa J, Kuhara S, Koga C, et al. Congenital granular cell tumor (congenital epulis) in the fetus: a case report. J Oral Maxillofac Surg 1997; 55(11):1356-9.DOI: 10.1016/s0278-2391(97)90202-0 